\title{
Development of a Low Calorie Ready-to-Serve Beverage from Hibiscus cannabinus $\mathrm{L}$
}

\author{
Sulochanamma G, Madhusudhan Rao D, Prabhakara Rao P G and Balaswamy K* \\ Council of Scientific and Industrial Research-Central Food Technological Research Institute (CSIR-CFTRI), Resource Centre, Hyderabad-500007, India
}

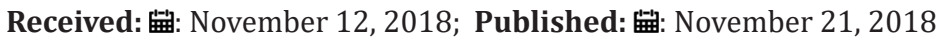

*Corresponding author: Balaswamy K, Council of Scientific and Industrial Research-Central Food Technological Research Institute (CSIR-CFTRI), Resource Centre, Hyderabad-500007, India

\begin{abstract}
Hibiscus cannabinus, a leafy vegetable is known for rich in fibre, minerals with high acidity. It is also known to be one of the sources of an antiobese factor (hydroxycitric acid). A low-calorie ready-to-serve (RTS) beverage was developed from H. cannabinus leaves using a natural sweetener (steviol glycoside). The beverage was prepared using the leaf aqueous extract, adjusting the acidity, and followed by the addition of a natural sweetener, steviol glycoside. The beverage was evaluated for changes in physicochemical and sensory parameters during a storage period of six months. The product was found to be acceptable for four months and scored very good (6.56) for overall quality after six months. A reduction in sweetness attribute was found when compared to control (8.0). The product was found to be shelf-stable with no microbial growth during storage. Significant decrease in steviol glycoside content (16.63\%) and hydroxycitric acid content (54.4\%) was observed after the end of storage. The RTS beverage from Hibiscus leaves with functional ingredients will ensure health and wellness of consumers.
\end{abstract}

Keywords: Hibiscus cannabinus; Low Calorie Ready To Serve Beverage; Steviol Glucoside; Hydroxycitric Acid

Abbreviations: RTS: Ready To Serve; ADI: Acceptable Daily Intake; CSP: Commercial Steviol Glucosides Powder; HCA: Hydroxycitric Acid; NEB: NonEnzymatic Browning; PCA: Plate Count Agar; DRBC: Dichloran Rose Bengal Chloramphenicol Agar; RT: Room Temperature

\section{Introduction}

Ready-to-serve (RTS) beverages made up of fruit pulp have greater amount of water that is useful for body balancing by preventing dehydration. Fruit drinks contain high percentage of sugar and provide a few vitamins and minerals. The consumption of fruit-based beverages in the form of fruit blends and smoothies is increasing due to public awareness on the presence of various functional ingredients beneficial to health. The limited intake of free sugars below $10 \%$ of total energy intake constitutes a healthy diet and further reduction to $<5 \%$ of total energy intake will result in additional health benefits [1]. The usage of various synthetic/ natural sweeteners in lieu of sugar is increasing day by day due to health concerns. Studies on sensory quality of synthetic sweeteners such as saccharin, acesulfame $\mathrm{K}$, aspartame, and neotame revealed that aspartame solution resembles the sweetness of sucrose solution [2]. The RTS beverages from amla juice and ginger juice prepared with aspartame as a sweetener, scored maximum for all sensory quality attributes when compared to saccharine [3]. In another experiment, thaumatin/sucralose (1:1) blend had a closer sensory profile with $7 \%$ sucrose solution during the preparation of mango nectar [4].
Stevia (Stevia rebaudiana), a natural sweetener aqueous extract was compared for sweetness with sugar and applied in eleven beverage recipes namely, milk, coffee, tea, gajar halwa, milkshake, kheer, curd, lemon water, custard, halwa, and lapsi. The results indicated that $1.5 \%$ of stevia extract yielded sweetness comparable to 5\% sugar in the products tested [5]. The procedure for the extraction of sweetener ingredients (steviol glycoside) from stevia leaves includes pre-treatment of leaves, hot water extraction, concentration, recrystalization, and separation. The steviol glycoside include substances such as Steviolbioside, Stevioside, Rebaudioside A, Rebaudioside B, Rebaudioside C (dulcoside B), Rubusoside, and dulcoside. The steviol glycoside contain a steviol backbone conjugated to several combinations of the sugar moieties such as glucose, rhamnose, xylose, fructose, and deoxyglucose [6]. The chemical properties, toxicity, legislation, extraction techniques and uses of stevia in the food industry were reviewed [7]. Steviol glycoside were permitted up to $200 \mathrm{mg} / \mathrm{kg}$ in carbonated water, soft drink concentrates, yogurts, fruit nectars, dairy-based flavored drinks and non-carbonated water-based beverages and a higher quantity of $360 \mathrm{mg} / \mathrm{kg}$ in jams, jellies and marmalades [8]. 
The steviol glucosides are 300 times sweeter than sugar and showed the negligible effect on blood glucose levels in humans and the EFSA (2010) prescribed an acceptable daily intake (ADI) limit of $4 \mathrm{mg} / \mathrm{kg}$ body weight/day [9]. On the other hand, commercial steviol glucosides powder (CSP) exhibited good antioxidant activity when evaluated by DPPH, FRAP and ABTS assays. The CSP exhibited $47.64 \%$ inhibition in DPPH activity at $100 \mu \mathrm{g} / \mathrm{ml}$ level [10]. H. cannabinus and H. sabdariffa (Roselle) belonging to family Malvaceae are found in the tropical and subtropical countries. They are termed as gongura in the local language in the southern Indian states. The physicochemical composition, uses, biological and pharmacological activities of Hibiscus was discussed thoroughly earlier [11]. H. cannabinus, red stemmed variety is generally preferred for its higher acidity for preparation of chutneys and pickles. Gongura based culinary preparations with pulses such as tur dhal, with non-vegetarian meats such as mutton, chicken and shrimp are popular in Southern India. It was indicated that gongura is a very rich source of iron, vitamins, folic acid and antioxidants essential for human health [12]. H. cannabinus leaves had a moisture content of $11.82 \%$, ash $5.11 \%$, lipids $2.33 \%$, crude fibre (29.61\%), protein (12.40\%) and carbohydrates (37.67\%) [13].

Seeds of Hibiscus are eaten roasted or ground in meals, while the leaves are consumed raw or cooked, or as a flavored vegetable. Literature is available on the preparation of beverages from Rosella (Hibiscus safdariffa), wherein calyces were used for the extraction of its bright red color. The plant extracts from Hibiscus varieties are known to possess an anti-obesity agent, L-hydroxycitric acid (HCA). HCA acts as a competitive inhibitor of the enzyme ATP-citrate lyase, which catalyzes the conversion of citrate and coenzyme A to oxaloacetate and acetyl coenzyme A (acetyl-CoA), primary building blocks of fatty acid and cholesterol synthesis [14]. Earlier workers [15] identified the principal acid (-)-hydroxycitric acid in the highly acidic fruits of Garcinia species, (+)-allo-hydroxycitric acid in the leaves of H. cannabinus, and its isomer in H. sabdariffa. The Hibiscus flowers (calyces) were used in the production of non-alcoholic beverages, wine, jam, jellies, and marmalades. Commercially, dried calyces from $H$. sabdariffa were extracted with hot water to yield an attractive red color, and then the ${ }^{\circ}$ Brix was adjusted with sugar to 13 for a beverage production [16]. Further, the extracts were flavored with orange, pineapple, and apple fruit pulps to enhance vitamin $\mathrm{C}$, mineral content and their acceptability [17]. So far utilization of leafy vegetables is not in practice to produce beverages. In the present study, an attempt has been made to utilize the leaves of $H$. cannabinus L. for producing a low calorie functional RTS beverage using steviol glucosides as a sweetener which will be an alternative way of consumption apart from regular traditional preparations.

\section{Materials and Methods}

\section{Materials}

Fresh $H$. cannabinus leaves were collected from the vegetable market, Uppal, Hyderabad. The chemicals were used in the study were procured from M/s. SD Fine Chem., Mumbai, India. The commercial stevia powder (steviol glycoside) was procured from M/s Stanpack Pharma Pvt Ltd, Mumbai, India. The analytical standard of hydroxycitric acid (HCA) was procured from Sigma Chemicals, USA. Microbiological media, plate count agar (HiMediaM091A) and dichloran rose bengal chloramphenicol agar (HiMedia-M1881) were obtained from HiMedia, Mumbai, India.

\section{Preparation of RTS Beverage}

H. Cannabinus leaves were separated manually from stems and soaked for $5 \mathrm{~min}$ in $2 \mathrm{ppm}$ chlorine (sodium hypochlorite) water for disinfection. The leaves were further washed with water to remove dust and adhering particles. Stems were separated manually to extract the red coloring pigments and used in the study. A portion of leaves were tray dried at $50 \pm 2{ }^{\circ} \mathrm{C}$ for proximate composition. Experiments were conducted for aqueous extraction of fresh leaves using ground leaves, chopped leaves with and without stem peel. The extraction of fresh leaves was carried out in boiling water at different ratios (1:5 to $1: 30$ ) for varying time periods ranging from 5 to $30 \mathrm{~min}$. After the treatments, the contents were filtered, and the filtrate was analyzed for $\mathrm{pH}$, acidity, and color. The filtrate was diluted with sterile and potable water and adjusted the acidity. The required sweetness was obtained with steviol at $15-30 \mathrm{mg} / 100 \mathrm{~mL}$ by comparing with a control RTS beverage wherein a standard ${ }^{\circ}$ Brix: acid ratio ( $15{ }^{\circ}$ Brix: $0.15 \%$ acidity, test drink) was followed. The beverage was preserved by hot filling process and stored for six months at room temperature $\left(29 \pm 3^{\circ} \mathrm{C}\right.$ ). A sweetener control (RTS beverage with sugar) was prepared for comparison during sensory evaluation.

\section{Physicochemical and Sensory Analysis}

The bottled RTS beverage kept for storage studies was drawn at regular intervals during the storage period as followed: 0, 2, 4 and 6 months. The beverage was analyzed for various physicochemical parameters such as ${ }^{\circ} \mathrm{Brix}$, acidity, $\mathrm{pH}$, non-enzymatic browning (NEB), total polyphenols, anthocyanins using standards methods reported [18]. Brix was measured by using Hand refractometer (Erma, Japan). The acidity was measured by titrating the known amount of sample with standard $\mathrm{NaOH}$ solution using Phenolphthalein as an indicator. The $\mathrm{pH}$ of beverage was measured by using single electrode $\mathrm{pH}$ meter (Hanna, England). Nonenzymatic browning (NEB) was carried out by addition of ethanol, filtration and measuring the absorbance at $440 \mathrm{~nm}$. Total polyphenol content was determined by extracting with $80 \%$ ethanol, color development with Folin-Ciocalteu reagent and reading optical density at $675 \mathrm{~nm}$. Anthocyanins were analysed by extracting with acidified alcohol and reading absorbance at $535 \mathrm{~nm}$. The changes in color units for brightness, red and yellow ( $\mathrm{L}^{*}, \mathrm{a}^{*}$, and $\mathrm{b}^{*}$ ) were recorded using a Hunter Lab colorimeter (UV-VIS1417, Hunter Lab, UK).

Steviol glucosides and HCA standards were prepared at $1 \mathrm{mg} /$ $\mathrm{mL}$ concentration, and $20 \mu \mathrm{l}$ was injected into HPLC system (LC 20AD Shimadzu, Japan). Steviol glycoside was identified using $\mathrm{NH}_{2}$ column $(250 \times 4.6 \mathrm{~mm}$, particle size $5 \mu)$ and using a mobile phase consisting of acetonitrile: water $(80: 20, v / v)$. Hydroxycitric acid was quantified using a $\mathrm{C}_{18}$ column $(250 \times 4.6 \mathrm{~mm}$, particle size $5 \mu)$ employing $0.0025 \mathrm{~N} \mathrm{H}_{2} \mathrm{SO}_{4}$ as the mobile phase [19]. Both steviol 
glucosides (Stevioside and Rebaudioside A) and HCA were detected at $210 \mathrm{~nm}$ at $6.9,11.9$ and $4.0 \mathrm{~min}$. when a flow rate of $1 \mathrm{~mL} / \mathrm{min}$ was optimized. The beverage samples were dissolved in respective mobile phases, filtered through $0.45 \mu \mathrm{m}$ membrane filter (Millipore, Merck, India) for determining the stevioside and HCA contents during the storage. Sensory analysis of the beverage products along with control was carried out by a well-trained panel of 8 judges. They were asked to score for sensory attributes like appearance, color, flavor, taste, overall acceptability using a 9 point Hedonic scale where score 1 is designated for dislike extremely and 9 for like extremely during initial and the storage period at RT [20].

\section{Microbiological Analysis}

The microbiological quality of the beverages was carried out by pour plate technique. The samples were prepared up to 10-2 dilution and plated on Plate Count Agar (PCA) for enumeration of viable mesophilic bacteria (Total Plate Count). Dichloran Rose Bengal Chloramphenicol agar (DRBC) was used for enumeration of yeast and molds. They were sampled in duplicate and incubated at $37{ }^{\circ} \mathrm{C}$ for two days, and $30^{\circ} \mathrm{C}$ for five days respectively [21-23]. The samples were analyzed initially and after 2, 4, 6 months of storage at room temperature (RT).

\section{Statistical Analysis}

The changes in physicochemical parameters were analyzed in triplicate, and the mean values are presented. The values presented for sensory parameters are the mean of 8 panelists with standard deviation. The data were analysed statistically by Analysis of Variance (ANOVA) using SPSS 19.0 to evaluate the significance at $\mathrm{P}<0.05$

\section{Results and Discussion}

\section{Changes in Physicochemical Parameters}

The fresh leaves possessed a moisture content of $86.51 \%$. The composition of dried leaves indicated moisture content of $5.09 \%$, total ash $5.44 \%$, crude fat $9.03 \%$, protein $19.03 \%$ and crude fibre $9.02 \%$ (Table 1). The results are comparable studies conducted with earlier [24]. The extraction of juice involved boiling of fresh leaves in water maintaining finely chopped leaves to water ratio at 1:10 for 15 min revealed the complete recovery of the pink color and total acidity. The juice was filtered through a four-layered muslin cloth to yield the clarified juice. The extract possessed $\mathrm{pH} 2.62$, acidity $0.30 \%$ and exhibited a bright pink-red color with $\mathrm{L}^{*}, \mathrm{a}^{*}$ and $\mathrm{b}^{*}$ values of 30.27, 8.01, 3.78 respectively in Hunter Lab colorimeter. The acidic nature of extract might have resulted complete recovery of color. The HCA content was quantified about $275 \mathrm{mg} / 100 \mathrm{~g}$ by HPLC. The water is known to be the optimal solvent for extraction of greatest quantity of functional compounds from $\mathrm{H}$. cannabinus leaves with the highest levels of antioxidant activity [25]. A steviol glycoside content of $20 \mathrm{mg} / 100 \mathrm{~mL}$ was optimized to yield the sweetness comparable with the test beverage with sugar $\left(15^{\circ} \mathrm{Brix}\right)$ and the acidity was adjusted to $0.18 \%$.

Table 1: Composition of dried H. cannabinus leaves.

\begin{tabular}{|c|c|}
\hline Parameter & Value \\
\hline Moisture, \% & 5.09 \\
\hline Total ash, \% & 5.44 \\
\hline Crude fat, \% & 9.03 \\
\hline Total protein, \% & 19.03 \\
\hline Crude fibre, \% & 9.02 \\
\hline Iron, $\mathrm{mg} / 100 \mathrm{~g}$ & 41.50 \\
\hline Phosphorous, $\mathrm{mg} / 100 \mathrm{~g}$ & 171.00 \\
\hline
\end{tabular}

Earlier, a process to produce a variety of low-calorie RTS fruit beverages from mango, jamun, pineapple, pomegranate and purple grapes was standardized using steviol glucosides at $20-35 \mathrm{mg} / 100 \mathrm{~mL}$ [26]. The physicochemical and microbiological quality of $H$. cannabinus RTS beverage samples are presented in Table 2 . The changes in ${ }^{\circ}$ Brix content of the beverage is negligible throughout the study. The variation in acidity was minor which maintained between $0.18-0.16 \mathrm{pH}$ at 2.7. The NEB values increased from 0.067 to 0.071 during storage. The light pink color of the beverage is due the anthocyanin content of $1.6 \mathrm{mg} / 100 \mathrm{~g}$. The Hunter color values of the RTS beverage were noted lower than extract as $32.58,2.58,4.52$ for $\mathrm{L}^{*}, \mathrm{a}^{*}, \mathrm{~b}^{*}$ respectively which changed to $33.84,0.57$ and 5.23 respectively after six months of storage. Studies on effect of temperature showed that the anthocyanins reduced to $13 \%$ at $50{ }^{\circ} \mathrm{C}$ and $39 \%$ at $80{ }^{\circ} \mathrm{C}$ [27]. In the present study, the significant decrease was observed in red units is in accordance with a significant reduction in total anthocyanin content from 1.61 to $0.44 \mathrm{mg} / 100 \mathrm{~mL}$ after storage of six month at RT (Table 3).

Table 2: Quality changes in H. cannabinus RTS beverage during storage.

\begin{tabular}{|c|c|c|c|}
\hline \multirow{2}{*}{ Parameter } & \multicolumn{3}{|c|}{ Storage Period (Months) } \\
\cline { 2 - 4 } & $\mathbf{0}$ & 2 & $\mathbf{4}$ \\
\hline${ }^{\circ}$ Brix & $0.50 \pm 0.00$ & $0.50 \pm 0.00$ & $0.50 \pm 0.00$ \\
\hline $\mathrm{pH}$ & $2.76 \pm 0.01$ & $2.62 \pm 0.01$ & $2.54 \pm 0.02$ \\
\hline Acidity, \% & $0.18 \pm 0.01$ & $0.17 \pm 0.01$ & $0.17 \pm 0.01$ \\
\hline NEB & $0.067 \pm 0.00$ & $0.068 \pm 0.00$ & $0.068 \pm 0.33$ \\
\hline $\mathrm{a}^{*}$ & $32.58 \pm 0.03$ & $33.00 \pm 0.2$ & $33.76 \pm 0.05$ \\
\hline $\mathrm{b}^{*}$ & $2.58 \pm 0.02$ & $1.48 \pm 0.01^{\mathrm{a}}$ & $0.071 \pm 0.00$ \\
\hline HunterLab values L* & $4.52 \pm 0.02$ & $4.62 \pm 0.01^{\mathrm{a}}$ & $0.07 \pm 0.02^{\mathrm{a}}$ \\
\hline Total polyphenols, $\mathrm{mg} / 100 \mathrm{~g}$ & $1.61 \pm 0.03$ & $1.24 \pm 0.0^{\mathrm{a}}$ & $4.71 \pm 0.02^{\mathrm{a}}$ \\
\hline
\end{tabular}




\begin{tabular}{|c|c|c|c|c|}
\hline Steviol glycosides, $\mathrm{mg} / 100 \mathrm{~g}$ & $17.68 \pm 0.18$ & $16.52 \pm 0.13^{\mathrm{a}}$ & $15.47 \pm 0.01^{\mathrm{a}}$ & $14.74 \pm 0.05^{\mathrm{a}}$ \\
\hline $\begin{array}{c}\text { Hydroxycitric acid, } \\
\mathrm{mg} / 100 \mathrm{~g}\end{array}$ & $275.27 \pm 4.26$ & $204.25 \pm 3.91^{\mathrm{a}}$ & $158.00 \pm 2.9^{\mathrm{a}}$ & $125.50 \pm 9.58^{\mathrm{a}}$ \\
\hline Total plate count, $\mathrm{cfu} / \mathrm{mL}$ & $<10.0$ & $<10.0$ & $<10.0$ & $<10.0$ \\
\hline Yeast and moulds, cfu/mL & $<1.0$ & $<1.0$ & $<1.0$ & $<1.0$ \\
\hline
\end{tabular}

Note: *N=3; a indicates significant difference at $\mathrm{P}<0.05$ in a row.

Table 3: Quality changes in H. cannabinus RTS beverage during storage.

\begin{tabular}{|c|c|c|c|c|}
\hline \multirow{2}{*}{ Parameter } & \multicolumn{4}{|c|}{ Storage Period (Months) } \\
\cline { 2 - 5 } & $\mathbf{0}$ & $\mathbf{2}$ & $\mathbf{4}$ & $\mathbf{6}$ \\
\hline Appearance & $8.00 \pm 0.38$ & $7.81 \pm 0.26$ & $7.69 \pm 0.46$ & $7.31 \pm 0.26^{\mathrm{a}}$ \\
\hline Colour & $7.50 \pm 0.53$ & $7.25 \pm 0.27$ & $7.13 \pm 0.35$ & $6.56 \pm 0.32^{\mathrm{a}}$ \\
\hline Flavour & $8.00 \pm 0.38$ & $7.63 \pm 0.23^{\mathrm{a}}$ & $7.56 \pm 0.18^{\mathrm{a}}$ & $6.88 \pm 0.23^{\mathrm{a}}$ \\
\hline Taste & $7.88 \pm 0.23$ & $7.75 \pm 0.27$ & $7.31 \pm 0.26^{\mathrm{a}}$ & $6.50 \pm 0.46^{\mathrm{a}}$ \\
\hline Overall Quality & $7.88 \pm 0.35$ & $7.75 \pm 0.27$ & $7.56 \pm 0.18$ & $6.56 \pm 0.50^{\mathrm{a}}$ \\
\hline
\end{tabular}

Note: * $\mathrm{N}=8$; a indicates significant difference at $\mathrm{P}<0.05$ in a row.

\section{Changes in Steviol Glucosides and Hydroxycitric Acid}

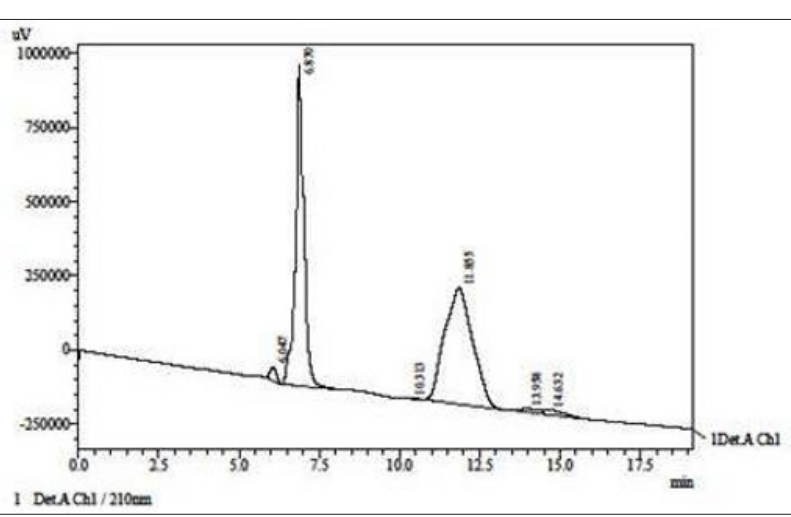

Figure 1: HPLC of commercial steviol glucoside.

HPLC analysis of steviol glycoside indicated the presence of two major peaks for Stevioside and Rebaudioside A along with other minor ingredients (Figure 1). Similarly, in the HPLC, standard HCA was detected at retention time of $4 \mathrm{~min}$ (Figure 2). Total steviol glycoside content of $17.68 \mathrm{mg} / 100 \mathrm{~mL}$ was noticed on the day of preparation by HPLC (Figure 3), which reduced to $14.74 \mathrm{mg} / 100 \mathrm{~mL}$ accounting for a loss of $16.63 \%$. During the storage of two months, the decrease of steviol glucosides amounted to $6.56 \%$. Reduction in steviol glucosides was also perceptible during sensory analysis as indicated by a lower score for sweetness. Hence, the addition of higher quantities of steviol glycoside $(>25 \mathrm{mg} / 100 \mathrm{~mL})$ can be recommended for retaining optimum sweetness in RTS beverages for six months storage. Other studies indicated the higher decrease in stevioside content (18\%) in a low-calorie orange nectar prepared with reduced sugar content and high stevioside content $(60 \mathrm{mg} / 100$ $\mathrm{mL}$ ) during storage at $25^{\circ} \mathrm{C}$ for 2 months [28]. Some studies revealed that degradation of Rebaudioside A into six secondary compounds in carbonated beverages at $\mathrm{pH}$ 2.8-4.2 at various temperatures (5$40{ }^{\circ} \mathrm{C}$ ) stored for six months [29]. Stevioside was found to be less stable than Rebaudioside A in different soft drinks after 24, 48, and
$72 \mathrm{~h}$ storage at $80^{\circ} \mathrm{C}$ [30]. A similar trend of decrease was observed when calculated for individual sweeteners such as Stevioside and Rebaudioside A in the present study from (Figure 3).

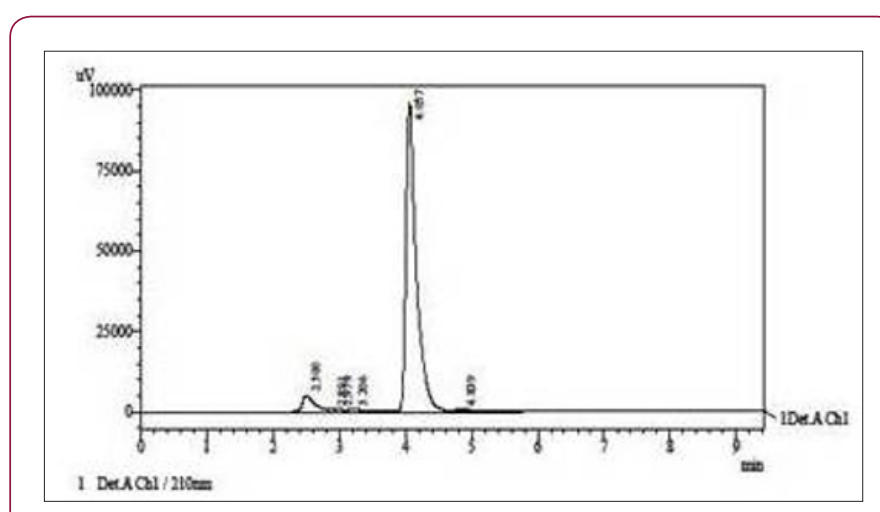

Figure 2: HPLC of standard Hydroxycitric acid.

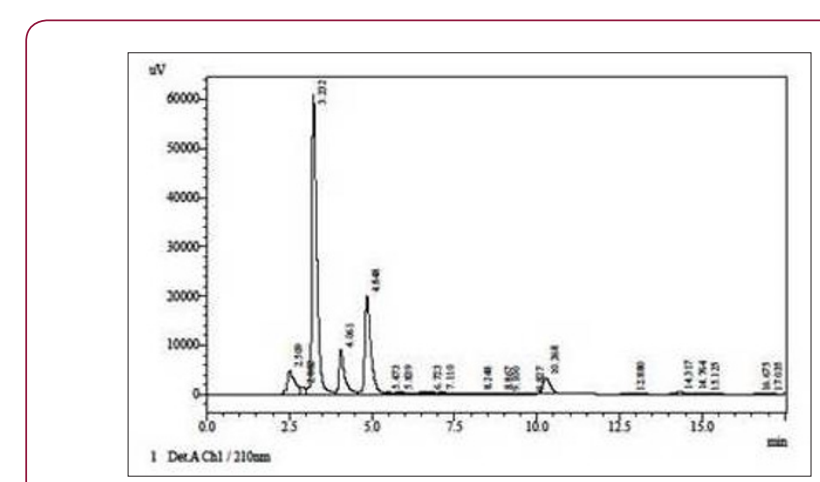

Figure 3: HPLC of Steviol glucosides in H. cannabinus RTS beverage.

HPLC analysis revealed the presence of HCA in the beverage at $275.27 \mathrm{mg} / 100 \mathrm{~mL}$ (Figure 4) the peak of which was confirmed by spiking with a standard on the day of preparation. Dilution of leaf extract and processing at higher temperature might have caused degradation of HCA content in the beverage. Significant reduction 
was noticed in HCA content to an extent of 25.8, 42.6 and $54.4 \%$ respectively after storage for 2,4 , and six months. Earlier studies reported HCA to an extent of $1.01 \mathrm{~g} / 100 \mathrm{~mL}$ in a formulation of Kokum RTS beverage [31]. Losses of HCA content to the extent of $17.96 \%$ and $15.57 \%$ were noticed in RTS beverage and fruit bar respectively at the end of two months storage. The losses in HCA content in kokum jam were two-fold when stored at RT compared to refrigerated conditions during storage for 90 days [32]. It was concluded that the shorter half-life of HCA to two months in water when prepared with or without heat treatment where beverage formulation contains 500mg Super Citrimax (HCA) and 150mg stevia [33].

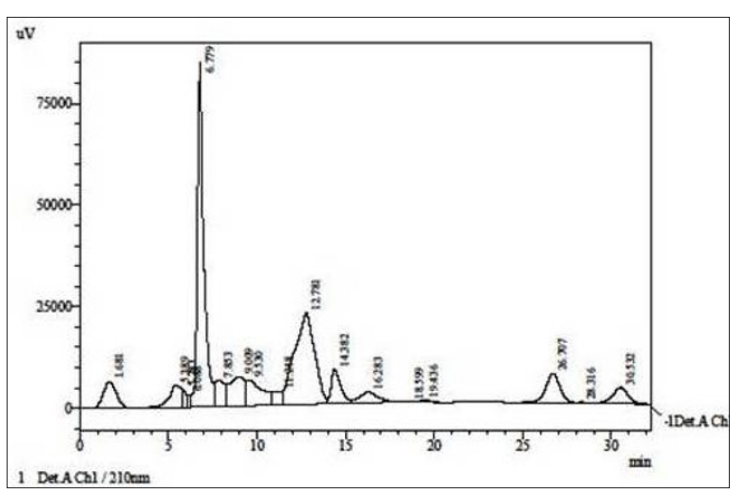

Figure 4: HPLC of hydroxycitric acid in H. cannabinus RTS beverage.

\section{Changes in Sensory Quality}

The sensory evaluation of the RTS beverage revealed its high acceptance by panelists on the day of preparation with an overall score of 7.88 which is similar to control (8.2). During the storage at RT, the low-calorie beverage maintained good score for overall quality (7.56) even though decrease in scores was observed for taste, and flavor after 4 months. After six months of storage, significant decrease was observed in scores of all sensory parameters (6.56) and the panel suggested for addition of more stevia/sweetness. The beverage showed reduced sweetness and increased acidity after six months. The control sample with sugar as a sweetener scored good (7.6) for overall quality compared to experimental beverage.

\section{Microbiological Quality}

The RTS beverage was found to be microbiologically safe as the growth of bacteria, yeast and molds were noted negligible on the day of preparation and no further growth after the hot-filling process and during storage for a period of six months. The hotfilling process is known as an effective technique in preserving beverages which are having $\mathrm{pH}$ below 4.6. The process not only help in removal of microorganisms during hot filling but also create anaerobic conditions for aerobic microbial growth by vacuum during cooling the bottles in addition to reducing oxidative deterioration of the beverage [34].

\section{Conclusion}

The RTS beverage was found to be shelf-stable and microbiologically safe during the period of 4 months. The acceptability of the beverage can be enhanced by the addition of higher steviol glycoside. The study further required the antioxidant activity and mineral content in the beverage for attention. The beverage from under-utilised $H$. cannabinus leaves with steviol glucosides can be popularized as a low-calorie functional drink useful for diabetic and obese populations.

\section{Acknowledgment}

The authors thank the Director, CSIR CFTRI, Mysore for permission to publish the data. The authors also thank Dr. G. Narsing Rao, Sr. Technician, CSIR CFTRI Resource Centre, Hyderabad for technical assistance and Mr. B. Naveen Kumar, Scientist, National Institute of Nutrition, Hyderabad for statistical analysis of data.

\section{Highlights}

a) Hibiscus cannabinus, a leafy vegetable is known for rich in fibre, minerals with high acidity.

b) They are generally consumed as chutney, chutney powder, spice mix and cooked dhal in India. The extract in acidic nature was consumed after sweetened for better palatability.

c) The Hibiscus extract was sweetened with a natural sweetener, steviol glucosides.

d) The presence of hydroxyl citric acid and addition of steviol glucosides brings the RTS beverage to functional food and widens the scope for commercialization.

\section{References}

1. WHO(2015) World Health Organization, "Healthy diet".

2. Sediva A, Panovska Z, Pokorny J (2006) Sensory profiles of sweeteners in aqueous solutions. Czech Journal of Food Science 24(6): 283-287.

3. Gaikwad KK, Singh S, Shakya BR (2013) Studies on the development and shelf life of low calorie herbal aonla-ginger RTS beverage by using artificial sweeteners. Journal of Food Processing Technology 4: 200.

4. Cadena RS, Cruz AG, Netto RR, Castro WF, Faria JAF, et al. (2013) Sensory profile and physicochemical characteristics of mango nectar sweetened with high intensity sweeteners throughout storage time. Food Research International 54(2): 1670-1679.

5. Renu M, Versha D (2009) Exploring the use of Stevia rebaudiana as a sweetener in comparison with other sweeteners. Journal of Human Ecology 25(2): 117-120.

6. FAO (2016) 82 $2^{\text {nd }}$ JECFA - Chemical and Technical Assessment (CTA).

7. Gonzalez C, Tapia M, Perez E, Pallet D, Dornier M (2014) Main properties of steviol glycosides and their potential in the food industry: a review. Fruits 69(2): 127-141.

8. FSSAI (2011) Food Safety and Standards Authority of India.

9. EFSA (2010) European Food Safety Authority. Scientific opinion on the safety of steviol glycosides for the proposed uses as a food additive. EFSA Journal 8: 1537.

10. Narsing Rao G, Prabhakar Rao PG, Balaswamy K, Satyanarayana A (2014) Antioxidant activity of stevia (Stevia rebaudiana $L$ ) leaf powder and a commercial stevioside powder. Journal of Food and Pharmaceutical Sciences 2: 32-38.

11. Da Costa Rocha I, Bonnlaender B, Sievers H, Pischel I, Heinrich M (2014) Hibiscus sabdariffa L. - A phytochemical and pharmacological review. Food Chemistry 165: 424-443. 
12. Gopalan C, Rama Sastri BV, Balasubramanian SC (2011) Nutritive Value of Indian Foods, Indian Council of Medical Research, New Delhi, National Institute of Nutrition, Hyderabad, India.

13. Kubmarawa D, Andenyang IFH, Magomya AM (2009) Proximate composition and amino acid profile of two non-conventional leafy vegetables (Hibiscus cannabinus and Haematostaphis barteri). African Journal of Food Science 3(9): 233-236.

14. Soni MG, Burdock GA, Preuss HG, Stohs SJ, Ohia SE, et al. (2004) Safety assessment of (-) hydroxycitric acid and Super CitriMax! a novel calcium/ potassium salt. Food and Chemical Toxicology 42(9): 1513-1529.

15. Lewis YS, Neelakantan S (1965) (-)-Hydroxycitric acid-the principal acid in the fruits of Garcinia cambogia desr. Phytochemistry 4(4): 619625.

16. Bolade MK, Oluwalana IB, Ojo O (2009) Commercial practice of roselle (Hibiscus sabdariffa $L$ ) beverage production: optimization of hot water extraction and sweetness level. World Journal of Agricultural Sciences 5(1): 126-131.

17. Fasoyiro SB, Babalola SO, Owosibo T (2005) Chemical composition and sensory quality of fruit-flavoured roselle (Hibiscus sabdariffa) drinks. World Journal of Agricultural Sciences 1(2): 161-164.

18. Ranganna S (1986) Hand book of analysis and quality control for fruits and vegetable products. In Ranganna S (Eds.) ( $2^{\text {nd }}$ Edn) Tata McGraw-Hill Publishing Company Limited, New Delhi, India.

19. Jayaprakasha GK, Sakariah KK (2000) Determination of (-) hydroxycitric acid in commercial samples of Garcinia cambogia extract by liquid chromatography with ultraviolet detection. Journal of Liquid Chromatography and Related Technologies 23(6): 915-923.

20. Amerine MA, Pangborn RM, Roessler EB (1965) Principles of Sensory Evaluation of Food. In Amerine MA, Pangborn RM, Roessler EB (Eds.) Academic Press, New York, USA.

21. APHA (2001) Compendium of Methods for the Microbiological Examination of Foods. In APHA (4 ${ }^{\text {th }}$ Edn.) American Public Health Association, Washington DC, USA.

22. Larry M, James TP (2006) Bacteriological Analytical Manual. In Larry M, James TP (Eds.) (8 ${ }^{\text {th }}$ Edn.), Revision A, Chapter 3. Aerobic Plate Count.

23. APHA (2001) Compendium of Methods for the Microbiological Examination of Foods. In APHA (Eds.) ( $4^{\text {th }}$ Edn.), American Public Health Association, Washington DC USA

ISSN: 2574-1241

DOI: 10.26717/BJSTR.2018.11.002077

Balaswamy K. Biomed J Sci \& Tech Res

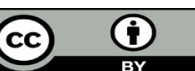

This work is licensed under Creative Commons Attribution 4.0 License

Submission Link: https://biomedres.us/submit-manuscript.php
24. Narsing Rao G, Balaswamy K, Srinivasulu K, Sulochanamma G, Venkateswaran G, et al. (2017) Development of an instant spice mix from gongura (Hibiscus cannabinus L.) for deep fat fried snacks and evaluation of its antioxidant activity. Indian Journal of Traditional Knowledge 16(3): 490-497.

25. Ryu J, Kwon SJ, Ahn JW, Jo YD, Kim S, et al. (2017) Phytochemicals and antioxidant activity in the kenaf plant (Hibiscus cannabinus L.). Journal of Plant Biotechnology 44: 191-202.

26. Balaswamy K, Prabhakara Rao PG, Narsing Rao G, Nagender A, Satyanarayana A (2014) Production of low calorie ready-to-serve fruit beverages using a natural sweetener, stevia (Stevia Rebaudiana L.). Focusing on Modern Food Industry 3: 59-65.

27. Shivon S, Viresh M, John JM (2017) Stability and degradation kinetics of crude anthocyanin extracts from H. sabdariffa. Food Science and Technology (Campinas) 37(2): 209-215.

28. Hosseini S, Goli SAH, Keramat J (2015) Production and characterization of low-calorie orange nectar containing stevioside. Journal of Food Science and Technology 52(10): 6365-6374.

29. Wolwer Rieck U, Tomberg W, Wawrzun A (2010) Investigations on the stability of stevioside and rebaudioside A in soft drinks. Journal of Agricultural and Food Chemistry 58(23): 12216-12220.

30. Prakash I, Clos JF, Chaturvedula VSP (2012) Stability of rebaudioside A under acidic conditions and its degradation products. Food Research International 48(1): 65-75.

31. Bafna PG (2013) Process development of kokum RTS beverage using response surface methodology (RSM). International Journal of Food and Nutritional Science 2(2): 1-7.

32. Bafna PG, Manimehalai N (2013) Process development of jam utilizing under exploited fruit kokum (Garcinia indica). The Journal of Food Technology, Photon 105: 146-152.

33. Witarsa SY (2011) Comparative stability of phytonutrients in functional beverages stored under different environments. M.Sc. Thesis, Ohio State University, USA.

34. Hariyadi P (2013) Hot-fill processing of beverages. Food Review International 1(1): 46-49.

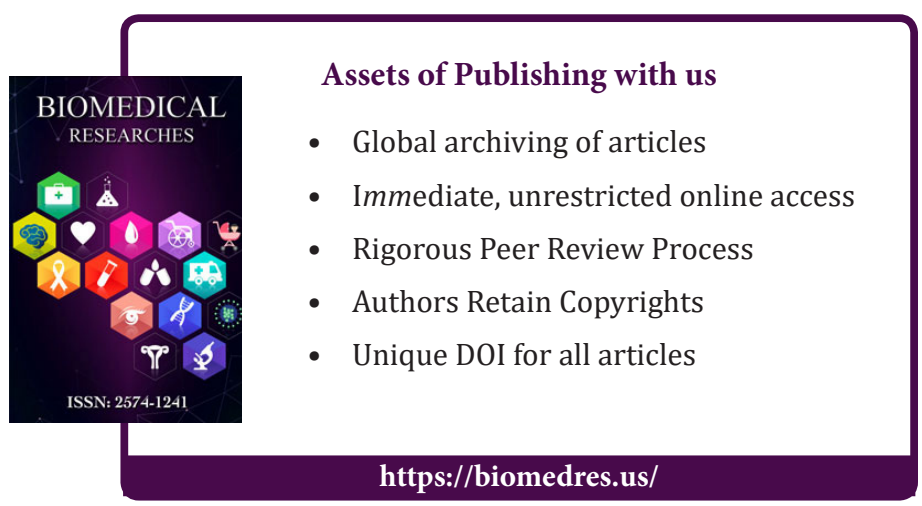

